\title{
Hubungan Faktor Suhu dan Kelembaban Dengan Kasus Demam Berdarah Dengue (DBD) di Kota Bandar Lampung
}

\author{
Devita Febriani Putri ${ }^{1}$, Tusy Triwahyuni ${ }^{1}$, Ismalia Husna ${ }^{1}$, Sandrawati ${ }^{2}$ \\ ${ }^{1}$ Departemen Parasitologi, Fakultas Kedokteran, Universitas Malahayati. \\ ${ }^{2}$ Mahasiswi Kedokteran, Fakultas Kedokteran, Universitas Malahayati.
}

\begin{abstract}
Abstrak
Demam Berdarah Dengue (DBD) merupakan penyakit tular vektor pada manusia yang disebabkan oleh virus dengue (DENV) dan disebarkan oleh nyamuk Aedes aegypti sebagai vektor utama. Kasus DBD di kota Bandar Lampung cenderung meningkat serta berpotensi menimbulkan Kejadian Luar Biasa (KLB) setiap tahunnya. Perubahan iklim dapat berpengaruh terhadap pola penyebaran dan meningkatkan resiko penularan DBD. Tujuan penelitian adalah untuk mengetahui korelasi antara faktor suhu dan kelembaban dengan kasus DBD di kota Bandar Lampung tahun 2016-2018. Jenis penelitian menggunakan data sekunder dengan metode rancangan korelasi. Data sekunder berupa kasus DBD didapatkan dari Dinas Kesehatan Kota Bandar Lampung serta data suhu dan kelembaban didapatkan dari Stasiun Meteorologi Klas IV Maritim Tanjung Karang. Analisis univariat dilakukan untuk mengetahui distribusi frekuensi kasus DBD, suhu dan kelembababan, dan untuk mengetahui hubungan antara variabel suhu dan kelembaban dengan DBD dilakukan uji korelasi Pearson. Hasil penelitian menunjukkan terdapat hubungan bermakna antara suhu dan kasus DBD dan tidak ada korelasi antara kelembaban dengan kasus DBD. Program pencegahan dan pemberantasan penyakit DBD dapat ditingkatkan melalui kerjasama Dinas Kesehatan Kota dan BMKG kota Bandar Lampung, agar masyarakat lebih meningkatkan kewaspadaan dini terhadap penyakit DBD ketika memasuki bulan tertentu (pada kondisi suhu rendah dan kelembaban tinggi) sesuai dengan informasi BMKG.
\end{abstract}

Kata Kunci : Suhu,Kelembaban, Demam Berdarah Dengue

\section{The Relationship between Temperature and Humidity Factors with Cases of Dengue Hemorrhagic Fever (DHF) in Bandar Lampung City}

\begin{abstract}
Dengue hemmoragic fever (DHF) is a vector-borne disease humans caused by dengue virus (DENV) and speread by Aedes aegypti mosquito as the main vector. Dengue cases in the city of Bandar Lampung tends to increase and has the potential to cause External Event Reguler (KLB) every year. Climate change can have an effect the pattern of speread and inscrease the risk of dengue transmission. The purpose of this study was to determine the corelation between Temperature and Humidity factors and cases DHF in the city of Bandar Lampung 20162018. This type of research data using secondary data with the correlation design method. Secondary data in the form of DHF cases obtained from the departement Bandar Lampung city Health and Temperature and Humidity data obtained from the Meteorology Station Klas IV Maritim Tanjung Karang. Univariate analysis was carried out to study the frequency distribution DHF cases, temperature and humidity, and to find out relationship between variable temperature and humidity with DHF were tested Pearson correlation.The results showed a significant relationship between temperature and DHF cases and there is no correlation between humidity with the DHF case. Dengue disease prevention and eradication program can be improved through collaboration between the City Health Office and BMKG the city of Bandar Lampung, so that people increase awareness premature against DHF when entering a certain month (at conditions of low temperature and high humidity) according to BMKG information.
\end{abstract}

Keywords: : Temperature,Humidity,DHF

Korespondensi: Devita Febriani Putri, Departemen Parasitologi Fakultas Kedokteran Universitas Malahayati, Jalan Pramuka no : 27 Bandar Lampung, mobile 0811796180,e-mail devita@malahayati.ac.id 


\section{Pendahuluan}

Demam Berdarah Dengue (DBD) adalah penyakit tular vektor yang disebabkan virus dengue dari genus Flavivirus yaitu virus dengue. Aedes aegypti merupakan jenis nyamuk yang berperan sebagai vektor utama penyebaran virus dengue ke manusia. Kasus DBD yang terdistribusi luas di negara tropis maupun subtropis di dunia. (Kreamer et al., 2015). Penyakit DBD dapat muncul sepanjang tahun dan dapat menyerang seluruh kelompok umur. Munculnya penyakit ini berkaitan dengan kondisi lingkungan dan perilaku masyarakat (Kemenkes RI, 2016).

Data World Health Organization (WHO) terdapat 1.016.612 kasus DBD dari 60 negara pada tahun 2000 - 2009. Asia menempati urutan pertama dari seluruh dunia dengan jumlah penderita DBD terbanyak setiap tahunnya. Sejak tahun 1968 hingga tahun 2009, negara Indonesia tercatat sebagai negara dengan kasus DBD tertinggi di Asia Tenggara (WHO, 2014).

Lampung merupakan salah satu Provinsi di Indonesia yang memiliki beberapa wilayah endemis DBD, salah satunya adalah Kota Bandar Lampung. Kasus DBD cenderung meningkat dan semakin luas penyebarannya serta berpotensi menimbulkan Kejadian Luar Biasa (KLB). Angka kesakitan (IR) selama 2010-2015 cenderung berfluktuasi. Angka kesakitan DBD tahun 2016 sebesar 73,39 per 100.00 penduduk (Dinkes, 2015).

Beberapa faktor resiko penyebab terjadinya DBD berkaitan dengan peningkatan transmisi virus dengue yakni vektor, penjamu, dan lingkungan. Salah satu faktor lingkungan fisik yang mempengaruhi penularan penyakit DBD adalah iklim. Parasit dan vektor penyakit sangat peka terhadap perubahan iklim. Iklim dapat berpengaruh terhadap pola penyakit infeksi karena agen penyakit baik virus, bakteri atau parasit, dan vektor bersifat sensitif terhadap suhu, kelembaban, kondisi lingkungan lainnya (Faldy dkk., 2015).

Penelitian sebelumnya menyatakan faktor iklim berupa suhu dan kelembaban mempengaruhi jumlah kasus DBD di suatu daerah (Wirayoga, 2013; Pohan, 2014). Namun ada pula penelitian yang menyatakan bahwa tidak ada hubungan antara suhu ataupun kelembaban dengan kasus DBD (Ariati dan Musadad, 2012; Bangkele, 2016; Chandra, 2019). Efek perubahan iklim khususnya perubahan suhu udara dan kelembaban terhadap
DBD penting diteliti untuk memprediksi variasi kasus DBD dan resiko yang berhubungan dengan dampak perubahan iklim.

\section{Metode}

Jenis penelitian ini merupakan penelitian yang menggunakan data sekunder dengan metode rancangan korelasi. Penelitian dilakukan di kota Bandar Lampung dan dilaksanakan pada November - Desember 2019. Populasi penelitian adalah seluruh data prevalensi DBD dan data suhu udara serta data kelembaban di Kota Bandar Lampung tahun 2016 - 2018. Pengambilan sampel dengan teknik total sampling, sehingga sampel penelitian sama dengan populasi penelitian.

Data yang digunakan merupakan data sekunder. Data prevalensi DBD per bulan diukur dengan cara observasi dokumen yaitu pengamatan dan pencatatan secara sistematis di kota Bandar Lampung tahun 2016 - 2018 dari Dinas Kesehatan Kota Bandar Lampung. Data suhu dan kelembaban diperoleh dari pencatatan data bulanan di Provinsi Lampung tahun 2016 2018 dari BMKG Bandar Lampung Provinsi Lampung.

Analisis data univariat memberikan gambaran distribusi kejadian DBD bulanan serta suhu dan kelembaban bulanan pada tahun 2016 - 2018. Analisis bivariat untuk menganalisis hubungan antara suhu dan kelembaban dengan kasus demam berdarah dengue, dengan menggunakan uji statistik korelasi pearson. Uji korelasi juga untuk mengetahui kekuatan dan arah hubungan dan arah hubungan antara suhu/kelembaban dengan kasus DBD.

\section{Hasil}

Berikut data distribusi kasus DBD (Gambar 1) yang didapatkan dari Dinas Kesehatan Kota Bandar Lampung pada tahun 2016 sampai tahun 2018. Total kasus DBD sebanyak 3209 kasus. 


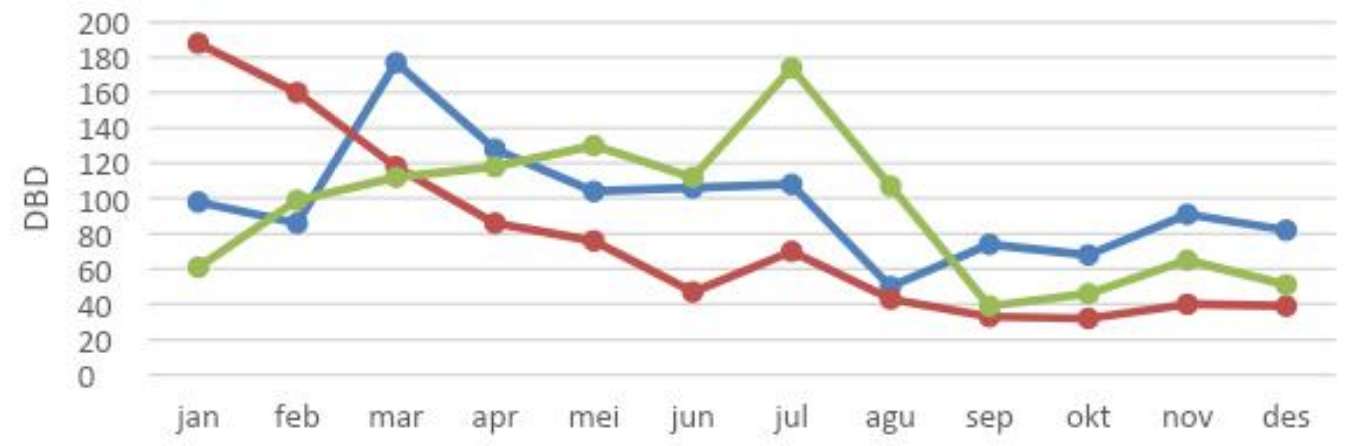

(Sumber : Dinas Kesehatan kota Bandar Lampung)

Gambar 1. Distribusi Frekuensi kasus DBD dikota Bandar Lampung tahun 2016-2018.

Total kasus DBD tertinggi pada tahun 2016 terjadi pada bulan Maret sebanyak 177 kasus dan terendah terjadi pada bulan Agustus sebanyak 50 kasus diperlihatkan pada Gambar 1. Pada tahun 2017, kasus tertinggi terjadi pada bulan Januari sebanyak 188 kasus dan kejadian terendah terjadi pada bulan Oktober sebanyak 32 kasus dan merupakan total kasus terendah sepanjang tahun 2016 - 2018. Tahun 2018, kasus tertinggi terjadi bulan Juli sebanyak 174 kasus dan kejadian terendah terjadi pada bulan September sebanyak 39 kasus.

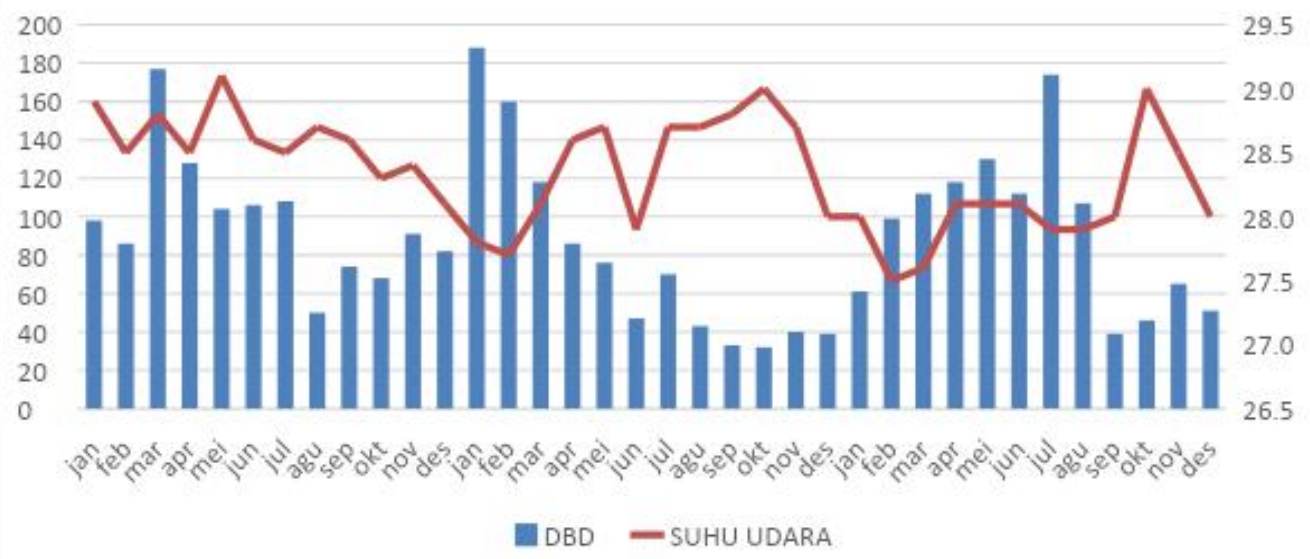

(Sumber : Dinas Kesehatan dan BMKG kota Bandar Lampung)

Gambar 2. Grafik Suhu udara dan kejadian DBD di kota Bandar Lampung Tahun 2016-2018.

Pola distribusi kasus DBD dan suhu sejak tahun 2016-2018 di Kota Bandar Lampung memperlihatkan perbedaan kecenderungan (trendline), kasus DBD mengalami peningkatan pada bulan November sampai dengan Maret, dan penurunan terjadi pada bulan April sampai Oktober (Gambar 3), sedangkan suhu berfluktuasi, penurunan suhu terjadi pada bulan Januari sampai Februari (2016); Mei sampai Juli (2017) dan Oktober sampai Desember (2019). Sementara trend peningkatan suhu udara terjadi pada bulan Februari sampai Mei dan Juni sampai Oktober.

Puncak kasus DBD dikota Bandar Lampung terjadi pada bulan Maret (tahun 2016), Januari (tahun 2017) dan Juli (tahun 2018). Pada bulan dan tahun tersebut suhu antara $27,8^{0} \mathrm{C}-28,8^{0}$ Nilai rata-rata untuk suhu tahun $2016-2018$ adalah $28,3^{0} \mathrm{C}$ (Tabel 1). Hasil uji korelasi (Pearson Correlation) menunjukkan terdapat hubungan antara suhu dan kasus DBD selama tahun 2016-2018 $(\mathrm{P}=0.041)$. Nilai $\mathrm{r}=-0,342$, dengan arah hubungan negatif, hal ini menunjukkan bahwa terdapat hubungan antara kasus DBD dengan suhu namun kekuatan korelasinya lemah.

Tabel 1. Hasil Analisis Korelasi Suhu udara dan Kasus DBD di Kota Bandar Lampung tahun 2016-2018.

\begin{tabular}{|c|c|c|c|c|}
\hline Variabel & $\mathrm{n}$ & $\begin{array}{l}\text { Mean } \\
( \pm \text { SD })\end{array}$ & $\rho$ & $\mathrm{r}$ \\
\hline Suhu & 36 & $\begin{array}{c}28,3 \\
(0,42)\end{array}$ & \multirow{2}{*}{0,041} & \multirow{2}{*}{$-0,342$} \\
\hline DBD & 36 & $\begin{array}{c}89 \\
(42)\end{array}$ & & \\
\hline
\end{tabular}




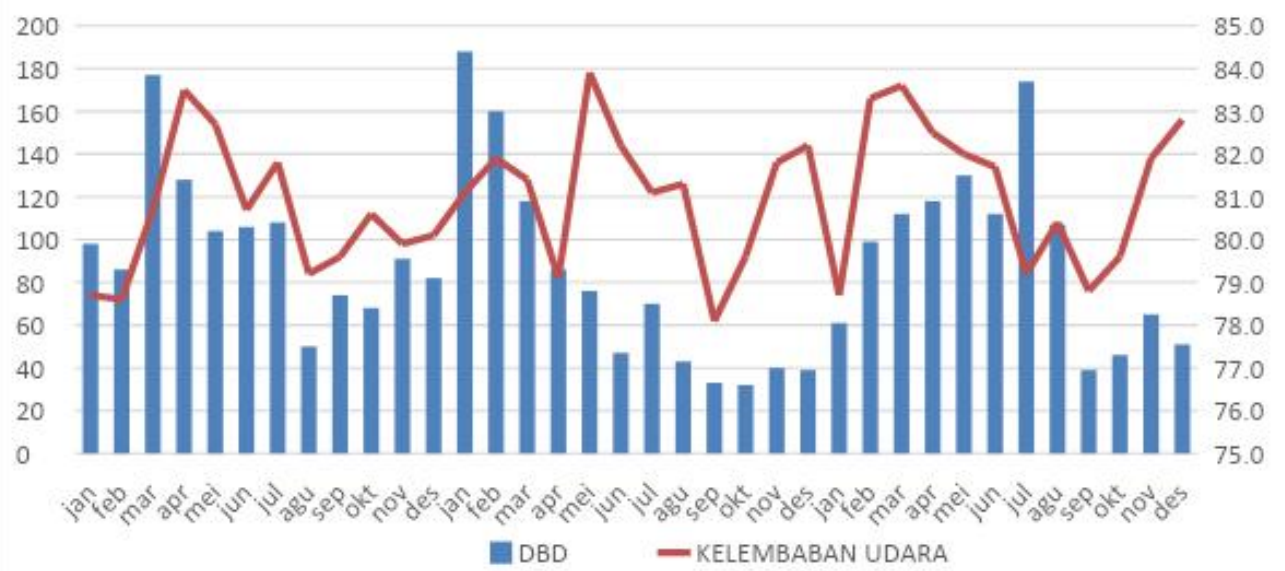

(Sumber : Dinas Kesehatan dan BMKG kota Bandar Lampung)

Gambar 3. Grafik Kelembaban dan Kasus DBD di kota Bandar Lampung Tahun 2016-2018.

Pada Gambar 3. memperlihatkan kelembaban udara berfluktuatif sepanjang tahun 2016 - 2018. Peningkatan terjadi pada bulan Februari sampai Mei dan Oktober sampai Desember. Sedangkan penurunan kelembaban terjadi pada bulan Juni sampai September dan bulan Januari. Kelembaban udara pada saat puncak kasus DBD berkisar 78,8\%- 81,1\%. Hasil uji korelasi (Tabel 2) antara kelembaban dan kasus DBD selama tahun 2016-2018 tidak menunjukkan adanya hubungan $(\mathrm{P}=0.201)$.

Tabel 2. Hasil Analisis Korelasi Kelembaban Udara dan Kasus DBD di Kota Bandar Lampung Tahun 2016-2018

\begin{tabular}{lcccc}
\hline \multicolumn{1}{c}{ Variabel } & $\mathrm{n}$ & $\begin{array}{c}\text { Mean } \\
( \pm \mathrm{SD})\end{array}$ & $\rho$ & $\mathrm{r}$ \\
\hline Kelembaban & 36 & $\begin{array}{c}80,9 \\
(1,6)\end{array}$ & & \\
& & 0,201 & 0,216 \\
DBD & 36 & $\begin{array}{c}89 \\
(42)\end{array}$ & & \\
\hline
\end{tabular}

\section{Pembahasan}

Puncak kasus DBD dikota Bandar Lampung terjadi pada bulan Maret (tahun 2016), Januari (tahun 2017) dan Juli (tahun 2018). Pada bulan dan tahun tersebut suhu antara $27,8^{0} \mathrm{C}-28,8^{0}$. Penularan DBD sangat erat kaitannya dengan perkembangan vektor yatu nyamuk Ae. aegypti. Nyamuk tidak bisa mengatur suhu tubuhnya sendiri terhadap perubahan lingkungan

maka proses metabolisme dan siklus hidupnya tergantung suhu dan lingkungan sekitarnya. Suhu rata - rata optimum untuk perkembangan nyamuk adalah berkisar $25{ }^{\circ} \mathrm{C}$ $27^{\circ} \mathrm{C}$. Pada suhu $35^{\circ} \mathrm{C}$ perkembangan nyamuk melambat atau pertumbuhan nyamuk akan terhenti sama sekali pada suhu kurang dari $10^{\circ} \mathrm{C}$ atau diatas $40^{\circ} \mathrm{C}$ (Susanna dan Sembiring, 2011). Suhu udara mempengaruhi aktivitas menggigit, istirahat dan perilaku kawin, penyebaran dan durasi siklus gonotrophik (Cahyati, 2006).

Telur Ae. aegypti akan mengalami perkembangan embrionisasi sempurna pada suhu $25^{\circ} \mathrm{C}-30^{\circ} \mathrm{C}$ selama 72 jam apabila telur menempel di penampungan air yang lembab (Umniyati, 2009). Hal ini didukung oleh penelitian laboratorium yang dilakukan Mohammed dan Chadee (2011) yang membuktikan bahwa pada suhu $24^{\circ} \mathrm{C}-25^{\circ} \mathrm{C}$, telur akan menetas $98 \%$ selama 48 jam.

Suhu juga mempengaruhi perkembangan virus dalam tubuh nyamuk dan penularan virus secara vertikal di nyamuk. Suhu optimum untuk propagasi virus pada nyamuk Ae. aegypti di laboratorium adalah $28^{\circ} \mathrm{C}$ (Joshi et al. 2002). Rohani et al. (2009) yang mengindikasikan penularan DENV 2 dan DENV 4 pada nyamuk Ae. aegypti, lebih efektif pada temperatur $30^{\circ} \mathrm{C}$ ketika periode inkubasi ekstrinsik lebih pendek, dan replikasi virus lebih tinggi dibandingkan pada temperatur $26{ }^{\circ} \mathrm{C}$ dan $28{ }^{\circ} \mathrm{C}$. Xiao et al. (2014), menyatakan bahwa temperatur $31^{\circ} \mathrm{C}$ merupakan temperatur terbaik untuk penularan DENV 2 pada nyamuk Ae. albopictus. Penelitian Joshi et al. (2002) membuktikan pada temperatur $25^{\circ} \mathrm{C}-29^{\circ} \mathrm{C}$, DENV 3 ditransmisikan secara transovarial pada nyamuk Ae. aegypti, sampai pada generasi ke-7.

Hasil uji korelasi antara suhu udara dan kasus DBD menunjukkan hubungan yang 
lemah dengan arah negative $(\mathrm{r}=-0,342)$. Hal ini sejalan dengan penelitian Wirayoga (2013) di Kota Semarang tahun 2006 - 2011 yang menyatakan bahwa ada hubungan yang signifikan dan berkorelasi negatif. Akan tetapi hasil penelitian ini tidak sejalan dengan penelitian yang dilakukan Bangkele (2016) di kota Palu menunjukkan tidak terdapat korelasi atau hubungan yang bermakna antara suhu dengan kejadian DBD selama tahun 2010 2014.

Kelembaban yang tinggi sangat dibutuhkan dan berpengaruh pada pernafasan nyamuk. Pernapasan nyamuk menggunakan pipa trakea yang disebut spirakel, spirakel yang terbuka tidak mempunyai pengaturan pada saat kelembaban rendah. Kelembaban rendah akan menyebabkan penguapan air dari dalam tubuh nyamuk sehingga cairan tubuh nyamuk keluar (Susan dan Sembiring, 2011). Pada kelembaban rendah (kurang dari 60\%) akan menyebabkan siklus hidup nyamuk menjadi pendek, dan tidak cukup untuk perkembang biakan DENV di dalam tubuh nyamuk (Sussana dan Sembiring, 2011; Depkes RI, 2004).

Penelitian skala laboratorium dilakukan Mohammed dan Chadee (2011) di Hindia barat membuktikan kelembaban $80 \%$ adalah kelembaban yang baik untuk perkembangan nyamuk dari stadium pradewasa sampai dewasa. Hal ini didukung oleh studi laboratorium dilakukan Joshi et al. (2002), kelembaban $80-85 \%$ bagus untuk perkembangan nyamuk dewasa sampai menghasilkan telur. Hasil studi ini didukung oleh Thu, et al. (1998) yang menyatakan propagasi DENV di nyamuk Ae. aegypti terus meningkat sampai hari ke 17 dengan kondisi kelembaban $87-90 \%$.

Hasil uji korelasi antara kelembaban udara dengan kasus DBD menyimpulkan tidak ada hubungan bermakna antara kelembaban udara dan kasus DBD. Hasil penelitian ini sejalan dengan penelitian Bangkele (2016) yang menyatakan tidak ada hubungan bermakna antara kelembaban dengan angka kejadian DBD di kota Palu selama tahun 2010 - 2014.

Hasil penelitian ini tidak sejalan penelitian Pohan (2014) dengan analisis regresi menyatakan terdapat hubungan positif bermakna antara kelembaban udara dan kejadian DBD. Alizkan (2017 ) juga menyatakan bahwa kejadian demam berdarah dengue di Kota Serang berhubungan bermakna dengan tingkat kelembaban. Hal ini juga didukung oleh penelitian Candra (2019) yang menyatakan kelembaban berpengaruh terhadap kejadian DBD di kota Jambi.

Kelembaban udara pada saat puncak kasus DBD dikota Bandar Lampung berkisar 79,2\%-81,1\%. Kelembaban tersebut termasuk dalam kelembaban optimal bagi vektor, dimana kelembaban optimum untuk pertumbuhan nyamuk Aedes aegypti ialah antara 60\% - 80\% (Sussana dan Sembiring, 2011; Mohammed dan Chadee, 2011). Sedangkan kelembaban udara pada bulan di kasus terendah DBD berkisar $78,8 \%$ - 81.1\%, juga termasuk dalam kelembaban optimum. Kemungkinan ini yang menyebabkan kelembaban udara tidak berpengaruh (secara analisis statistik) pada total kasus DBD yang terjadi di Kota Bandar Lampung. Yanti (2004) menyatakan kelembaban udara tidak berpengaruh secara langsung pada total kasus DBD, melainkan berpengaruh pada umur nyamuk Aedes aegypti yang merupakan vektor penularan DBD.

Kesimpulan dari hasil penelitian adalah terdapat hubungan bermakna antara suhu dan jumlah kasus DBD di kota Bandar Lampung, dan kelembaban tidak berkorelasi dengan jumlah kasus DBD di kota Bandar Lampung.

Suhu dan kelembaban berpengaruh penting pada replikasi DENV dalam tubuh nyamuk, dan merupakan salah satu faktor yang berkontribusi terjadinya KLB DBD (Thu et.al, 1998). Program pencegahan dan pemberantasan penyakit DBD dapat ditingkatkan melalui kerjasama Dinas Kesehatan Kota dan BMKG kota Bandar Lampung, agar masyarakat lebih meningkatkan kewaspadaan dini terhadap penyakit DBD ketika memasuki bulan tertentu (pada kondisi suhu rendah dan kelembaban tinggi) sesuai dengan informasi BMKG.

Perlu dikaji lebih lanjut variabel iklim lainnya seperti curah hujan, penyinaran matahari, arah angin yang diduga berpengaruh pada kasus DBD dengan rentang waktu yang lebih lama. Kajian ini memberikan informasi penting dalam pengembangan strategi pengendalian DBD dari segi vektor, dan melengkapi sistem kewaspadaan dini (early warning system) pada KLB DBD di Kota Bandar Lampung.

\section{Daftar Pustaka}

Alizka, U. (2017). Analisis Korelasi Kelembaban Udara Terhadap Epidemi Demam Berdarah Yang Terjadi Di Kabupaten Dan Kota Serang. Jurnal Ilmiah Penelitian dan Pembelajaran Fisika,Vol.3 No.1 :23-29. 
Ariati J, Musadda AD. (2012). Kejadian Demam Berdarah Dengue (DBD) dan Faktor Iklim di Kota Batam, Provinsi Kepulauan Riau. Jurnal Ekologi Kesehatan, Vol. 11(4):279-286.

Bangkele E.Y, NurSafriyanti. (2016). Hubungan Suhu Dan Kelembapan Dengan Kejadian Demam Berdarah Dengue (DBD) Di Kota Palu Tahun 2010-2014 . Jurnal Ilmiah Kedokteran, Vol.3 No.2 :40-50.

BMKG. 2019. Data Suhu udara dan kelembaban Kota Bandar Lampung: BMKG Stasiun Meteorologi Klas IV Maritim Tanjung Karang.

Cahyati WH, Suharyo. (2006). Dinamika Aedes Aegypti sebagai vektor Penyakit. Jurnal Kesehatan Masyarakat,Vol.2 No 1 :3848.

Chandra E. 2019. Pengaruh Faktor Iklim, Kepadatam Penduduk dan Angka Bebas Jentik (ABJ) Terhadap Kejadian Demam Berdarah Dengue (DBD) di Kota Jambi. Jurnal Pembangunan Berkelanjutan. eISSN: 2622-2310 (e); 2622-2302 (p), Volume 1. no (1) 2019 DOI: https://doi.org/10.22437/jpb.v21i1.5101

Depkes RI, Ditjen PPM\&PLP. (2004) Pencegahan dan pemberantasan Demam Berdarah Dengue, Jakarta: Depkes RI

Dinas Kesehatan Kota Bandar Lampung. (2015). Profil Kesehatan Kota Bandar Lampung tahun 2015. Bandar Lampung.

Dinas Kesehatan Kota Bandar Lampung. 2019. Rekapitulasi kasus demam berdarah dengue 2016-2018. Bandar Lampung.

Faldy R, Kaunang WPJ, Pandelaki AJ. (2015). Pemetaan Kasus Demam Berdarah Dengue Di Kabupaten Minahasa Utara. Jurnal Kedokteran Komunitas dan Tropik.3(1): 73-81.

Joshi, V., Mourya D.T., Sharma, R.C. (2002). Persistence of Dengue-3 Virus Through Transovarial Transmission Passage in Successive Generations of Aedes aegypti Mosquitoes. Am. J. Trop. Med. Hyg. 67: 158-161.
Kemenkes RI. (2016). Situasi DBD di Indonesia. Jakarta.

Kraemer, M.U.G, Sinka, M.E., Duda, K.A., Mylne, A.Q.N., Shearer, F.M., et al. (2015). The global distribution of the arbovirus vectors Aedes aegypti and Ae. albopictus. eLife. 4:1-18.

Mohammed, A., Chadee, D.D. (2011). Effect of Different Temperature regimens on the Development of Ae. aegypti (L) (Diptera: Culicidae) Mosquitoes. Acta Tropica.119: 38-34.

Pohan, Zoelkarnain. (2014). Hubungan Iklim Terhadap Kasus Demam Berdarah Dengue (Dbd) Di Kota Palembang Tahun 2003- 2013. [Skripsi]. Palembang: Universitas Sriwijaya.

Rohani, A., Wong, Y.C, Zamree, I., Lee, H.L., Zurainee, M.N., (2009). The Effect of Extrinsic Incubation Temperature on Development of Dengue Serotype 2 and 4 Viruses in Aedes aegypti L. Southeast As. J. Trop. Med. Pub. Health. 40 (5): 942-50.

Thu, H., M., Aye, K., M., Thein, S. (1998). The Effect of Temperature and Humidity on Dengue Virus Propagation in Aedes aegypti Mosquitos. Southeast Asian J Trop Med Public Health. 29(2): 280-4.

Susanna, D., Sembiring, J.T.U. (2011). Diptera. Entomologi Kesehatan (Artropoda Pengganggu Kesehatan dan Parasit yang Dikandungnya). Universitas IndonesiaPress. Jakarta. 34-44.

Umniyati, S.R. (2009). Tehnik Imunositokimia dengan Antibodi Monoklonal DSSC7 untuk. Kajian Patogenesis Infeksi dan Penularan Transovarial Virus Dengue serta Surveilansi Virologis Vektor Dengue. Disertasi. Program Ilmu Kedokteran dan Kesehatan, Fakultas Kedokteran, Universitas Gadjah Mada, Yogyakarta.

WHO. (2014). Dengue and Severe Dengue. Geneva.

Wirayoga, Mustazahid Agfadi. 2013. Hubungan Kejadian Demam Berdarah Dengue Dengan Iklim Di Kota Semarang 
Tahun 2006- 2011. UJPH 2 (4) (2013). ISSN 2252-6528.

Xiao, F.Z., Zhang, Y., Deng, Y.Q., He, S., Xie, H.G., Zhou, N.X., Yang Y.S. (2014). The Effect of Temperature on Extrinsic Incubation Period and Infection Rate of Dengue Virus Serotipe 2 in Aedes albopictus. Arch. Virol. 159:3053-3057. 